\title{
The Revitalization of Character Education Based on Pancasila in The Global Era
}

\author{
Margison A. W. B. Blegur \\ Magister Pendidikan Sejarah, Universitas Sebelas Maret Surakarta \\ margisonblegur@gmail.com
}

\section{Article History}

accepted 23/03/2021

approved 10/04/2021

published 20/04/2021

\begin{abstract}
There is character degradation caused by rapid global progress and development and indirectly demands that humans be able to adapt to existing needs, while the purpose of writing this scientific paper is how the Indonesian people are more aware of and appreciate the importance of living up to existing values. the values contained in Pancasila. In writing this scientific paper the writer uses historical research methods. In this historical research method, the researcher uses several reference sources in the form of relevant journals and books that support this writing. The result is that there are several obstacles that often occur on the surface of everyday life, namely: first, a lack of mutual respect among others; second, the things of the World take top priority in terms of living together (the attitude of Individualism); third, decreased practice of the values that exist in Pancasila. An attitude of mutual respect and prioritizing togetherness is very important to be instilled back in the community so that these values are still upheld because they are part of the values of Pancasila and the NKRI slogan, namely Bhineka Tunggal Ika.
\end{abstract}

Keywords: character education, Pancasila, revitalization

\begin{abstract}
Abstrak
Terjadinya degradasi karakter yang diakibatkan oleh kemajuan dan perkembangan global yang pesat serta secara tidak langsung ikut menuntut manusia untuk bagaimana bisa menyesuaikan dengan kebutuhan-kebutuhan yang ada, adapun tujuan dari penulisan karya ilmiah ini ialah bagaimana masyarakat Indonesia lebih menyadari dan menghayati bagaimana pentingnya mengamalkan nilai-nilai yang terdapat dalam Pancasila. Dalam penulisan karya ilmiah ini penulis menggunakan metode penelitian sejarah. Dalam metode penelitian sejarah ini, peneliti menggunakan beberapa sumber referensi berupa jurnal yang relevan dan buku-buku yang mendukung dalam penulisan ini. Hasil dari adapun beberapa kendala yang sering terjadi pada permukaan kehidupan sehari-hari yaitu: pertama, kurangnya rasa saling menghargai antara sesama; kedua, hal-hal Dunia menjadi prioritas utama dalam hal kehidupan bersama (sikap Individualisme); ketiga, menurunnya pengamalan akan nilai-nilai yang ada pada Pancasila. Sikap nilai saling menghargai dan mengutamakan kebersamaan sangat penting untuk ditanamkan kembali kepada masyarakat supaya nilai tersebut tetap dijunjung tinggi karena menjadi bagian daripada nilai-nilai Pancasila dan Semboyan NKRI yaitu Bhineka Tunggal Ika.
\end{abstract}

Kata kunci: Pancasila, pendidikan karakter, revitalisasi

Social, Humanities, and Education Studies (SHEs): Conference Series https://jurnal.uns.ac.id/shes

p-ISSN 2620-9284

e-ISSN 2620-9292 


\section{PENDAHULUAN}

Perkembangan di era globalisasi merupakan suatu tahap yang menjadi batu loncatan bagi setiap insan yang dimana telah memberikan dampak yang sangat luas dalam berbagai aspek kehidupan dari hal-hal yang dianggap. Merupakan hal yang sangat luar biasa dalam hal ini menyangkut dengan perkembangan dalam berbagai bidang kehidupan salah satunya yaitu bidang pendidikan, yang dimana merupakan suatu fondasi penting dalam pembangunan di era globalisasi masa kini, globalisasi sendiri telah menjadi suatu acuan atau faktor pendorong bagi setiap insan agar bisa dapat menyatukan berbagai hal yaitu dari segi pendidikan dan karakter yang berpusat pada konsep atau ideologi bangsa yanitu Pancasila.

Demikian, pada kenyataan yang dialami pada saat ini tidak berjalan lurus sesuai dengan cita-cita yang ingin digapai akibat dari keberlangsungan proses globalisasi yang merambah ke semuah aspek kehidupan, sehingga pada konsep pendidikan yang menjadi fondasi awal dari suatu pergerakan perubahanpun di goncangkan dengan degradasi karakter yang kian hari semakin menyusut, akibat dari kerasnya arus globaliosasi tersebut.

Integrasi pendidikan karakter sangatlah menjadi hal yang penting, artinya bahwa perkembangan di era global ini menuntut setiap insan agar perlu adanya penyesuaian dengan maraknya perkembangan sehingga terjadi keseimbangan, pada prinsipnya ialah tetap berpegang teguh pada ideology Pancasila yang menjadi pedoman dalam keberlangsungan kehidupan sehingga tidak terjadi penyimpanganpenyimpangan yang dapat mempersulit proses pengintegrasian tersebut.

Pendidikan karakter berlandaskan pada nilai-nilai agama, Pancasila, budaya bangsa, dan tujuan pendidikan nasional. Keempat hal tersebut juga sekaligus menjadi sumber pendidikan karakter yang diuraikan sebagai berikut: Pertama, Agama Setiap warga negara Indonesia wajib beragama. Oleh sebab itu kehidupan seseorang, masyarakat dan bangsa selalu didasari pada ajaran agama dan kepercayaannya. Kehidupan bernegara dan berpolitik juga dilandasi dengan nilai-nilai agama. Oleh sebab itu pendidikan karakter harus berlandaskan padanilai-nilai agama atau aturanaturan atau kaidah-kaidah yang bersumber dari agama. Kedua, Pancasila Panca Sila adalah dasar Negara Kesatuan Republik Indonesia (NKRI). Pancasila tercantum dalam Pembukaan Undang-Undang Dasar 1945. Disamping itu penjabarannya terdapat dalam pasal-pasal UUD 1945, sehingga dapat Dikatakan bahwa Panca Sila merupakan pedoman dalam hidup bermasyarakat dan bernegara, berpolitik, hukum, ekonomi, budaya dan seni. Ketiga, Budaya Setiap bangsa memiliki budaya, begitu pula Indonesia juga memiliki budaya. Nilai-nilai budaya merupakan dasar dalam pemaknaan berkomuniksi dalam masyarakat. Misalnya pada suku Bugis-Makassar ada budaya "Siri" dalam bahasa Bugis kata "Siri" berarti malu. Pemaknaan kata malu dalam bermasyarakat misalnya seorang mahasiswa "malu kalau ada mata kulianya yang tidak lulus" sehingga mahasiswa tersebut belajar dengan baik sehingga tidak ada mata kuliahnya yang tidak lulus. Keempat, Tujuan Pendidikan Nasional Undang-Undang Nomor 20 tahun 2003 tentang Sistem Pendidikan Nasional dinyatakan bahwa Pendidikan Nasional berfungsi mengembangkan kemampuan dan membentuk watak serta peradaban bangsa yang bermatabat dalam rangka mencerdaskan kehidupan bangsa. Bertujuan "untuk mengembangkan peserta didik agar menjadi manusia yang beriman dan bertakwa kepada Tuhan yang Maha Esa, berakhlak mulia, sehat, berilmu, cakap, kreatif, mandiri, dan menjadi warga negara yang demokrasi, serta bertanggung jawab". Berdasarkan bunyi tujuan pendidikan nasional tersebut terdapat karakterkarakter yang harus dimiliki oleh anak-anak bangsa. (Kosim M, 2011: 88-99)

Fondasi yang kuat akan dapat melahirkan generasi-generasi penerus bangsa yang bermartabat, sehingga terciptanya globalisasi yang tidak menyimpang dari norma-norma yang berlaku dalam masyarakat, artinya bahwa dalam proses pengrevitalisasian tersebut maka dengan sendirinya pemerosotan atau degradasi 
terhadap karakter tersebut akan kembali ke permukaan dan secara tidak langsung telah terbantahkan akan kuatnya globalisasi yang melampaui akan kualitas karakter bangsa.

Dalam membangun sumber daya manusia yang penuh rasa cinta tana air, yaitu dengan prinsip Pancasila sebagai pedoman dalam keberlangsungan kehidupan, maka perlu adanya prinsip atau keyakinan dalam diri setiap insan yang berperan sebagai sumber dalam pembentukan atau yang menjadi tiang pengyokong sehingga dapat lebih optibal dalam proses keberlangsungan tersebut, serta dapat tercapai cita-cita bangsa, lewat penanaman karakter, hal tersebut dapat menjadi faktor utama dalam proses kestabilan kehidupan berbagsa dan bernegara.

\section{METODE}

Dalam artikel ini, peneliti menggunakan penelitian studi pustaka. Penelitian ini termasuk dalam golongan penelitian kualitatif karena data yang dikumpulkan tidak dalam bentuk angka, melainkan dari semua bahan-bahan tertulis seperti buku, jurnal, internet dan artikel terkait lainnya. Peneliti membaca dan mencatat kemudian menganalisis segala sesuatu yang berkaitan dengan pembahasan dalam artikel ini yakni tentang bagaimana merevitalisasi kembali nilai-nilai Pancasila melalui pendidikan karakter di era global ini.

\section{Pendidikan Karakter}

\section{HASIL DAN PEMBAHASAN}

Pendidikan karakter merupakan suatu usaha yang dilakukan secara sadar dan terencana serta terarah dalam mengembangkan seluruh potensi sikap manusia dengan tujuan untuk memiliki sikap yang baik atau kepribadian yang baik dalam pikiran, perkataan dan dalam perilaku setiap hari.

Munculnya gagasan pendidikan karakter, dijelaskan oleh Nopan Omeri (2015:165) bahwa para ahli menganggapnya sebagai sebuah keniscayaan karena merupakan hal yang lumrah dalam teori pendidikan bahwa pendidikan karakter atau pembentukan watak merupakan tujuan umum pengajaran dan budi pekerti di sekolah.

Pendidikan adalah proses belajar untuk menjadi lebih baik. Hal ini dijelaskan oleh Kompri (2015:17) bahwa, "Pendidikan mengarahkan manusia pada kehidupan yang lebih baik, menyangkut derajat kemanusiaan untuk mencapai tujuan hidupnya." Dalam konteks ini, dapat dipahami bahwa makna pendidikan adalah menanamkan nilai-nilai tertentu ke dalam pribadi anak didik atau siswa. Dalam artikelnya, Ali Muhtadi (2010: 32) mengutip pendapat dari Driyarkara yang mengemukakan bahwa, "Pendidikan pada dasarnya adalah usaha untuk memanusiakan manusia."

Selanjutnya, ditambahkan oleh Evinna Cindra Hendriana dan Arnold Jacobus ( 2016: 25-29) bahwa, "Pendidikan artinya proses pengubahan sikap dan perilaku seseorang atau kelompok dalam usaha mendewasakan manusia. Kemudian mengacu pada Dinn Wahyudin, dijelaskan bahwa pendidikan adalah humanisasi (upaya memanusiakan manusia) yaitu suatu upaya dalam rangka membantu manusia (peserta didik) agar mampu hidup sesuai dengan martabat kemanusiaannya (Evinna Cindra Hendriana dan Arnold Jacobus, 2016: 25-29). Pernyataan tersebut dapat dipahami bahwa pendidikan tidak dapat diartikan hanya sekadar membantu pertumbuhan secara fisik, melainkan mencakup keseluruh pertumbuhan dan perkembangan pribadi dalam konteks lingkungan yang memiliki peradaban.

Sedangkan pendidikan menurut Yahya Khan (2010: 1) adalah "Sebuah proses yang menumbuhkan, mengembangkan, mendewasakan, menata serta mengarahkan." Dalam konteks tersebut, pendidikan juga diartikan sebagai proses pengembangan berbagai macam potensi yang ada dalam diri manusia agar dapat berkembang dengan baik yang bermanfaat bagi dirinya sendiri dan juga bagi lingkungan sekitar dimana ia berada. 
Secara etimologis, karakter berasal dari bahasa latin kharakter, kharassein, kharax dalam bahasa Inggris: character, dan dalam bahasa Indonesia: karakter yang diartikan sebagai tabiat, watak, sifat-sifat kejiwaan, akhlak atau budi pekerti yang membedakan seseorang dari yang lain. Sedangkan dalam bahasa Yunani ialah character dari kata charassein yang berarti membuat tajam atau membuat dalam. (Gunawan, 2012:1). Karakter dapat dijelaskan oleh Nashir (2013:10), bahwa merupakan perilaku baik yang membedakan dari 'tabiat' yang dimaknai perilaku buruk.

Karakter adalah sikap yang nampak dalam kehidupan setiap hari dalam bertindak. Karakter juga berkaitan dengan keinginan seseorang dalam melakukan hal yang baik, memiliki rasa peduli terhadap orang lain, kondisi dari pemikiran kritis dan alasan moral, serta pengembangan keterampilan dari setiap individu dan emosi yang menyebabkan kemampuan individu untuk bekerja dengan efektif setiap saat bersama orang lain. Menurut Kemendiknas (Nashir, 2013:10), menguraikan bahwa karakter adalah watak, tabiat, akhlak atau kepribadian seseorang yang terbentuk dari hasil internalisasi sebagai kebajikan (virtues) yang diyakini yang dipergunakan sebagai landasan dalam berpikir, bersikap dan bertindak. Sementara Qomari berpendapat (Kuswantoro, 2015:35) dengan mengemukakan bahwa karakter merupakan kumpulan tata nilai untuk menuju suatu sistem yang mendasari pemikiran, sikap dan perilaku yang ditampilkan.

Dari uraian diatas, maka dapat dipahami bahwa pendidikan merupakan proses yang dilakukan untuk mendidik, mengajarkan, juga membimbing setiap orang untuk menjadi lebih baik. Sedangkan karakter memiliki kedudukan yang sangat penting dalam kehidupan setiap orang. Nilai-nilai pendidikan karakter perlu untuk terus dikembangkan baik itu di sekolah, keluarga, lembaga keagaaman dan juga pada masyarakat luas. Pada umumnya sumber dari nilai-nilai pendidikan karakter adalah dari agama, budaya dan juga dari Pancasila serta tujuan pendidikan nasional. Dengan demikian, pendidikan karakter merupakan proses atau sistem penanaman nilai-nilai yang baik kepada setiap orang dalam pikiran, tingkah laku, akhlak.

\section{Tujuan Pendidikan Karakter}

Tujuan pendidikan karakter menurut Thomas Lickona (dalam Mahmud, 2012:23) adalah untuk membentuk kepribadian seseorang melalui pendidikan budi pekerti, yang hasilnya akan terlihat dalam tindakan nyata seseorang. Maksudnya adalah tingkah laku yang baik, jujur, bertanggung jawab, menghormati orang lain, kerja keras dan sebagainya. Sementara Aristoteles juga mengemukakan pendapatnya bahwa karakter itu berkaitan erat dengan kebiasaan yang nyata dalam tingkah laku (dalam Yaumi, 2014:82).

Tujuan pendidikan karakter difokuskan dalam penanaman nilai dan reformasi kehidupan sehingga dapat menciptakan karakter dan karakter yang mulia, secara seimbang yang dapat dilakukan dalam kehidupan sehari-hari secar kontinu. Menurut Handayani dan Indartono (2016:511) tujuan pendidikan karakter adalah untuk mendorong lahirnya anak-anak yang baik yaitu bertumbuh dengan karakter yang baik, bertumbuh dengan kapasitas dan komitmen untuk melakukan yang terbaik. Dalam konteks ini, anak-anak melakukan banyak hal yang benar dan memiliki kecenderungan untuk punya tujuan dalam hidup.

Dalam rangka lebih memperkuat proses pelaksanaan pendidikan karakter, maka pada satuan pendidikan telah mengidentifikasi 18 nilai yang bersumber dari agama, budaya dan Tujuan Pendidikan Nasional yang dikemukakan oleh Kemendiknas (2011:8). Berikut uraian nilai-nilai karakter.

Tabel 1. Nilai Dan Deskripsi Nilai Pendidikan Karakter

\begin{tabular}{|l|l|l|}
\hline No & Nilai Karakter & Deskripsi \\
\hline 1 & Religius & $\begin{array}{l}\text { Sikap dan perilaku yang patuh dalam melaksanakan } \\
\text { ajaran agama yang dianutnya, toleran terhadap } \\
\text { pelaksanaan ibadah agama lain, dan hidup rukun dengan }\end{array}$ \\
\hline
\end{tabular}




\begin{tabular}{|c|c|c|}
\hline & & pemeluk agama lain. \\
\hline 2 & Jujur & $\begin{array}{l}\text { Perilaku yang didasarkan pada upaya menjadikan dirinya } \\
\text { sebagai orang yang selalu dapat dipercaya dalam } \\
\text { perkataan, tindakan, dan pekerjaan. }\end{array}$ \\
\hline 3 & Toleransi & $\begin{array}{l}\text { Sikap dan tindakan yang menghargai perbedaan agama, } \\
\text { suku, etnis, pendapat, sikap, dan tindakan orang lain } \\
\text { yang berbeda dari dirinya. }\end{array}$ \\
\hline 4 & Disiplin & $\begin{array}{l}\text { Tindakan yang menunjukkanperilaku tertib dan patuh } \\
\text { pada berbagai ketentuan dan peraturan. }\end{array}$ \\
\hline 5 & Kerja keras & $\begin{array}{l}\text { Tindakan yang menunjukkan upayasungguh-sungguh } \\
\text { dalammengatasiberbagaihambatanbelajar dan tugas, } \\
\text { serta menyelesaikan tugas dengan sebaik-baiknya. }\end{array}$ \\
\hline 6 & Kreatif & $\begin{array}{l}\text { Berpikir dan melakukan sesuatu untuk menghasilkan } \\
\text { cara atau hasilbaru dari sesuatu yang telah dimiliki. }\end{array}$ \\
\hline 7 & Mandiri & $\begin{array}{l}\text { Sikap dan perilaku yang tidak mudah tergantung pada } \\
\text { orang lain dalam menyelesaikan tugas-tugas. }\end{array}$ \\
\hline 8 & Demokratis & $\begin{array}{l}\text { Cara berpikir, bersikap, dan bertindak yang menilai sama } \\
\text { hak dan kewajiban dirinya dan orang lain. }\end{array}$ \\
\hline 9 & Rasa ingin tau & $\begin{array}{l}\text { Sikap dan tindakan yang selalu berupaya untuk } \\
\text { mengetahui lebih mendalam dan meluas dari sesuatu } \\
\text { yang dipelajarinya, dilihat, dan didengar. }\end{array}$ \\
\hline 10 & $\begin{array}{l}\text { Semangat } \\
\text { kebangsaan }\end{array}$ & $\begin{array}{l}\text { Cara berpikir, bertindak, dan berwawasan yang } \\
\text { menempatkan kepentingan bangsa dan negara di atas } \\
\text { kepentingan diri dan kelompoknya. }\end{array}$ \\
\hline 11 & Cinta tanah air & $\begin{array}{l}\text { Cara berpikir, bersikap, dan berbuat yang menunjukkan } \\
\text { kesetiaan, kepedulian dan penghargaan yang tinggi } \\
\text { terhadap bahasa, lingkungan fisik, sosial, buday, } \\
\text { ekonomi, politik dan bangsa. }\end{array}$ \\
\hline 12 & $\begin{array}{l}\text { Menghargai } \\
\text { prestasi }\end{array}$ & $\begin{array}{l}\text { Sikap dan tindakan yang mendorong dirinya untuk } \\
\text { menghasilkan sesuatu yang berguna bagi masyarakat, } \\
\text { dan mengakui, serta menghormati keberhasilan orang } \\
\text { lain. }\end{array}$ \\
\hline 13 & $\begin{array}{l}\text { Bersahabat/ } \\
\text { komunikatif }\end{array}$ & $\begin{array}{l}\text { Tindakan yang memerlihatkan senang berbicara, bergaul } \\
\text { dan bekerja sama dengan orang lain. }\end{array}$ \\
\hline 14 & Cinta damai & $\begin{array}{l}\text { Sikap, perkataan dan tindakan yang menyebabkan orang } \\
\text { lain merasa senang dan aman atas kehadiran dirinya. }\end{array}$ \\
\hline 15 & Gemar membaca & $\begin{array}{l}\text { kebiasaan menyediakan waktu untuk membaca berbagai } \\
\text { bacaan yang memberikan kebajikan bagi dirinya. }\end{array}$ \\
\hline 16 & Peduli lingkungan & $\begin{array}{l}\text { Sikap dan tindakan yang selalu berupaya mencegah } \\
\text { kerusakan pada lingkungan alam di sekitarnya, dan } \\
\text { mengembangkan upaya-upaya untuk memperbaiki } \\
\text { kerusakan alam yang sudah terjadi. }\end{array}$ \\
\hline 17 & Peduli sosial & $\begin{array}{l}\text { Sikap dan tindakan yang selalu ingin memberi bantuan } \\
\text { pada orang lain dan masyarakat yang membutuhkan. }\end{array}$ \\
\hline 18 & Tanggung jawab & $\begin{array}{l}\text { Sikap dan perilaku seseorang untuk melaksanakan tugas } \\
\text { dan kewajibannya, yang seharusnya dia lakukan, } \\
\text { terhadap diri sendiri, masyarakat, lingkungan (alam, } \\
\text { sosial dan budaya), negara dan Tuhan Yang Maha Esa }\end{array}$ \\
\hline
\end{tabular}

Pendidikan karakter sebenarnya tidak dapat dilepaskan dari faktor pendidikan yang membentuknya: jati diri, nilai moral, kepekaan terhadap lingkungan sosialnya, agama, keanekaragaman budaya dan kebanggaannya pada bangsa sendiri. Maka, pendidikan karakter jelaslah merupakan sebuah upaya pembentukan pribadi yang 
mampu menemukan jati dirinya memahami nilai moral, kebajikan, agama, budaya dan kebanggaan kebangsaan yang dirancang dan dilatih sehingga pribadi yang dihasilkan mampu bertindak sesuai dengan jati dirinya tersebut.

Pendidikan karakter terkait dengan bidang-bidang lain, khususnya budaya, pendidikan, dan agama. Ketiga bidang kehidupan terakhir ini berhubungan erat dengan nilai-nilai yang sangat penting bagi manusia dalam berbagai aspek kehidupannya. Budaya atau kebudayaan umumnya mencakup nilai-nilai luhur yang secara tradisional menjadi panutan bagi masyarakat. Pendidikan, selain mencakup proses transfer dan transmisi ilmu pengetahuan juga merupakan proses sangat strategis dalam menanamkan nilai dalam rangka pembudayaan anak bangsa. Sementara itu, agama juga mengandung ajaran tentang berbagai nilai luhur dan mulia

\section{Nilai-nilai Pancasila}

Nilai atau value (dalam bahasa Inggris) termasuk dalam bidang kajian filsafat. Hal-hal yang berkaitan dengan nilai dibahas dan dipelajari oleh salah satu cabang filsafat, yaitu filsafat nilai (Axiology, Theory Of Value). Selain itu, filsafat juga sering diartikan sebagai ilmu tentang nilai-nilai (Saiin, 2017: 183). Dalam tulisannya, Bambang Doereso (dalam Kaelan, 2010: 39), menjelaskan bahwa terdapat tiga filsafat nilai, yakni: pertama, nilai itu suatu realitas yang abstrak, yang berarti nilai itu ada secara nyata dalam kehidupan manusia, tetapi nilai itu juga abstrak (tidak dapat diindera), dan yang dapat diamati hanyalah objek yang bernilai tersebut; kedua, nilai memiliki sifat normatif, artinya nilai memiliki sifat ideal (das sollen); ketiga, nilai berfungsi sebagai pendorong atau motivator, dan manusia adlaha pendukung nilai. Berarti manusia bertindak sesuai dengan dorongan oleh nilai yang diyakininya.

Sedangkan Pancasila secara etimologi berasal dari bahasa Sansekerta, yang terdiri dari dua suku kata, yakni panca yang berarti lima dan sila yang berari dasar. Oleh karena itu, Pancasila berarti mempunyai lima dasar. Asmaroini (2017: 51) menjelaskan bahwa Pancasila itu terdiri dari panca dan sila. Nama panca diusulkan oleh Ir. Soekarno sedangkan sila diusulkan oleh salah seorang ahli bahasa. Pancasila dirasakan sudah sempurna dan mencakup segala aspek pada bangsa Indonesia. Dalam buku Sutasoma yang dikarang oleh Empu Tantular (dalam Saiin, 2017: 184), mengatakan bahwa Pancasila ini mempunyai arti lima kesusilaan (Pancasila Karma), yakni: tidak boleh melakukan kekerasan, tidak boleh mencuri, tidak boleh berjiwa dengki, tidak boleh bohong, dan tidak boleh meminum minuman keras.

Pancasila merupakan dasar negara Indonesia. Sebagai dasar negara, Pancasila memiliki nilai-nilai agama dan budaya yang terkandung dan melekat pada kehidupan masyarakat maupun kerajaan. Pancasila sebagai bangsa pemersatu bangsa yang beraneka ragam suku, ras, agama dari Sabang sampai Merauke. Perkembangan Pancasila ini dimulai dari masa kerajaan hingga saat ini Indonesia sudah merdeka. Istilah Pancasila sudah dikenal zaman kerajaan Sriwijaya dan Majapahit (Dermawan, dalam Devi Angraini, dkk., 2020:12).

Nilai-nilai Pancasila yaitu nilai-nilai yang terkandung dalam setiap sila-sila di dalam Pancasila dimana saling memiliki keterkaitan dan secara utuh tidak dapat dipisahkan yang dijadikan suatu ukuran, patokan, anggapan dan keyakinan dalam kehidupan masyarakat. Berikut uraian nilai-nilai yang terkandung dalam sila-sila Pancasila, yakni:

\section{Ketuhanan Yang Maha Esa}

Sila Ketuhan Yang Maha Esa mengandung nilai-nilai yang meliputi dan menjiwai keempat sila lainnya. Dalam sila ini terkandung nilai bahwa negara yang didirikan adalah sebagai manifestasi tujuan manusia sebagai makhluk Tuhan Yang Maha Esa. Oleh karena itu, segala hal yang berkaitan dengan pelaksanaan dan penyelenggaraan negara, hukum dan peraturan perundang-undangan negara, kebebasan dan HAM haru dijiwai nilai-nilai keTuhanan Yang Maha Esa. (Chairiyah, 2014: 57) 


\section{Kemanusiaan Yang Adil dan Beradab}

Kemanusiaan Berasal dari kata manusia, yang berarti makhluk yang berbudaya dengan memiliki potensi pikir, rasa karsa dan cipta. Karena potensi yang dimilikinya itu manusia tinggi martabatnya. Dengan budi nuraninya, manusia menyadari nilai-nilai dan norma-norma. Kata "kemanusiaan" diartikan sebagai hakikat dan sifat-sifat khas manusia sesuai dengan martabatnya. Selanjutnya, kata "adil" berarti wajar, yaitu sepadan dan sesuai dengan hak dan kewajiban seseorang. Keputusan dan tindakan yang diambil didasarkan pada suatu obyektivitas, dan tidak pada subyektivitas. Kata "beradab" berasal dari kata adab, sinonim dengan kata sopan dan berbudi. Dalam konteks ini, maksudnya adalah sikap hidup, keputusan dan tindakan selalu berdasarkan pada nilai-nilai keluhuran budi, kesopanan dan kesusilaan. Adab terutama mengandung tata kesopanan, kesusilaan atau moral. Dengan demikian beradab berdasarkan nilai-nilai kesusilaan, bagian dari kebudayaan. (Syarbaini, 2012: 39)

\section{Persatuan Indonesia}

Persatuan berasal dari kata satu, yang berarti utuh dan tidak terpecah-pecah. Persatuan mengandung arti bersatunya bermacam-macam corak yang beraneka ragam menjadi satu kesatuan. Dalam konteks ini, persatuan mencakup persatuan dalam arti ideologis, politik, ekonomi, sosial budaya dan keamanan. Persatuan Indonesia adalah persatuan bangsa yang mendiami wilayah Indonesia yang bersatu karena didorong untuk mencapai kehidupan kebangsaan yang bebas, dalam wadah negara yang merdeka dan berdaulat. Persatuan Indonesia merupakan faktor yang dinamis, dalam kehidupan bangsa Indonesia yang bertujuan untuk melindungi segenap bangsa dan seluruh tumpah darah Indonesia, memajukan kesejahteraan umum, serta mewujudkan perdamaian kehidupan dunia yang abadi. (Syarbaini, 2012: 39)

\section{Kerakyatan Yang Dipimpin Oleh Hikmat Kebijaksanaan Dalam Permusyawaratan/ Perwakilan}

Kerakyatan berasal dari rakyat, yaitu sekelompok manusia yang berdiam di satu wilayah negara tertentu. Rakyat meliputi seluruh Indonesia itu dan tidak membedakan fungsi dan profesinya. Kerakyatan adalah rakyat yang hidup dalam ikatan negara. Dengan adanya sila ini, maka berarti bangsa Indonesia menganut demokrasi baik secara langsung maupun tidak langsung. Dalam konteks ini, demokrasi tidak langsung (perwakilan) sangat penting dalam wilayah negara yang luas serta penduduk yang banyak. Pelaksanaan demokrasi sekalipun sulit diwujudkan dalam dalam modern. Akan tetapi dalam beberapa hal tertentu dapat terlaksana, seperti dalam memilih kepala negara atau sistem referendum.

Kerakyatan yang dipimpin oleh hikmat kebijaksanaan dalam permusyawaratan/ perwakilan, dalam arti bahwa kekuasaan tertinggi berada di tangan rakyat. Kerakyatan juga bisa disebut kedaulatan rakyat. Hikmat kebijaksanaan berarti penggunaan pikiran atau akal yang sehat dengan selalu mempertimbangkan persatuan dan kesatuan bangsa, kepentingan rakyat dan dilaksanakan dengan sadar, jujur dan bertanggung jawab serta didorong dengan etika yang baik sesuai dengan hati nurani. Permusyawaratan adalah suatu tata cara khas Republik Indonesia dengan tujuan untuk merumuskan ataupun memutuskan suatu hal dengan berdasarkan kebulatan pendapat atau mufakat. Perwakilan adalah suatu sistem dalam arti tata cara (prosedur) mengusahakan turut sertanya rakyat mengambil bagian dalam kehidupan bernegara melalui lembaga perwakilan. (Syarbaini, 2012: 39)

\section{Keadilan sosial bagi seluruh rakyat Indonesia}

Keadilan sosial yang dimaksud tidak sama dengan pengertian sosialistis atau komunalistis. Karena keadilan sosial yang dimaksud dalam sila ini bertolak dari pengertian bahwa antara pribadi dan satu sama lain dalam masyarakat tidak dapat dipisahkan. Tempat hidup dan perkembangan dalam masyarakat dapat terjadi secara peribadi. Sedangkan pribadi adalah komponennya masyarakat. Dalam konteks ini, tidak diperbolehkan terjadi praktik dalam masyarakat sosialistis atau komunalistis yang 
hanya mementingkan masyarakat. Sebaliknya yang berlaku dalam negara liberal yang segala sesuatu dipandang titik beratnya dari pribadi atau individu. (Syarbaini, 2012: 39)

Keadilan sosial juga mengandung arti tercapainya keseimbangan antara kehidupan pribadi dan masyarakat. Dapat dipahami bahwa kehidupan manusia meliputi kehidupan jasmani dan rohani. Maka keadilan itupun meliputi keadilan dalam memenuhi tuntutan hidup jasmani serta keadilan memenuhi tuntutan kehidupan rohani secara seimbang (keinginan material dan spiritual). Hakikat keadilan sosial bagi seluruh rakyat Indonesia dinyatakan dalam alinea kedua pembukaan UUD 1945 yang berbunyi: "Dan perjuangan kemerdekaan kebangsaan Indonesia telah lahirlah negara Indonesia, yang merdeka, bersatu berdaulat, adil dan makmur" (Saiin, 2017:187)

Dari keseluruhan penjelasan diatas, maka kelima sila dalam Pancasila tersebut tercantum dalam pembukaan UUD 1945 yang memiliki nilai-nilai yang dapat dijadikan sebagai fondasi yang kuat dalam membangun bangsa dan negara Indoensia.

\section{Revitalisasi Pendidikan Karakter Berbasis Pancasila di Era Global}

Maksud dari revitalisasi pendidikan karakter berbasis Pancasila adalah bagaimana cara menanamkan/ menumbuhkan kembali nilai-nilai yang tersurat dan tersirat dalam Pancasila sebagai dasar negara. Pada kenyataannya Indonesia saat ini berada di tengah-tengah perkembangan dunia yang samakin pesat dengan melihat semua keadaan yang serba modern, kemajuan terknologi yang begitu canggih, serta era globalisasi di semua aspek kehidupan manusia yang didalamnya mencakup aspek ilmiah maupun aspek aspek sosial. Dalam hal ini, yang di maksud dengan aspek ilmiah adalah posisi dan lokasi, kekayaan alam, dan kemampuan penduduk Indonesia. Sedangkan yang meliputi aspek sosial adalah ideologi, politik, sosial budaya, pertahanan dan keamanan.

Franz Magnis Suseno (2012:11), menjelaskan bahwa kita mempunyai etika nasional yang teruraikan didalam Pancasila. Etika dalam Pancasila bukan sebuah rumusan melainkan merupakan prasyarat agar bangsa Indonesia bisa maju bersama, damai sejahtera dan memiliki solidaritas sosial yang tinggi. Selanjutnya, Suseno juga merumuskan etika Pancasila dalam lima pedoman untuk mudah dimengerti oleh masyarakat, yakni: pertama, tidak boleh ada tekanan, ancaman atau paksaan dalam hal agama; kedua, bertindak secara beradab dalam situasi apapun; ketiga, memiliki komitmen untuk maju bersama; keempat, bersatu sukseskan demokrasi; kelima, saling memperhatikan antara satu sama lain. Chairiyah (2014:59) mengatakan bahwa, kelima pedoman diatas muncul sebagai reaksi atas kondisi perilaku masyarakat yang sangat mengkhawatirkan seperti saat ini. Nilai-nilai Pancasila sebagai wujud dan tujuan dari cita-cita bangsa Indonesia di era globalisasi ini semakin diabaikan bahkan ditinggalkan. Oleh karena itu, diupayakan agar adanya revitalisasi kembali karakter bangsa di era globalisasi melalui pendidikan karakter.

Dalam masyarakat Indonesia yang sangat beraneka ragam corak dan budayanya ini, kemampuan untuk mengendalikan diri dan kepentingan adalah suatu sikap yang mempunyai arti sangat penting dan bahkan merupakan sesuatu yang sangat diharapkan, pada gilirannya akan menumbuhkan keseimbangan masyarakat (Chairiyah, 2014: 59). Dalam pandangan Pancasila, hubungan sosial yang selaras, serasi, dan seimbang antara individu dan masyarakatnya tidak netral, melainkan dijiwai oleh nilai-nilai yang terkandung dalam sila-sila Pancasila sebagai kesatuan. Manusia harus hidup dan bekerjasama dengan manusia lain dalam bermasyarakat (Kaelan, 2010:31).

Dari pembahasan diatas, dapat memberikan pemahaman bahwa pendidikan Pancasila merupakan sebuah aspek yang sangat penting dalam upaya untuk membangun karakter generasi bangsa. Berikut terhadap beberapa hal yang dikemukakan oleh Chairiyah dalam upaya merevitalisasi kembali nilai-nalai pancasila melalui Pendidikan karakter di era global ini, yakni: 
a. Peningkatan Perhatian Masyarakat Terhadap Nilai-Nilai Pancasila. Dalam menghalau dampak negatif berkembangnya berbagai ideologi negara lain termasuk kuatnya pengaruh ideologi leluhur ditengah-tengah masyarakat, maka perhatian masyarakat terhadap nilai-nilai pancasila harus kembali dapat ditingkatkan melalui serangkaian upaya dan kegiatan sebagai berikut: a). Mengunggah dan mensosialisasikan secara terus menerus eksistensi dan keberadaan ideologi pancasila sebagai pemersatu untuk membangkitkan kembali rasa nasionalisme dikalangan pemimpin politik, pengusaha, pemuda dan tokohtokoh agama. b). Meningkatkan filter/saringan masyarakat terhadap eksistensi ideologi kapitalis dan liberalis yang mencoba untuk memecah belah Indonesia disemua aspek politik, ekonomi dan sosial budaya. c). Meningkatkan intensitas pemberian materi pelajaran pendidikan Pendidikan pancasila seperti pendidikan moral pancasila pada tataran teori maupun praktik kepada para siswa/mahasiswa pada semua jenjang pendidikan (Chairiyah, 2014: 59-60).

b. Penyamaan Interpretasi Pemahaman Nilai-Nilai Pancasila. Kenyataan saat ini, interpretasi masyarakat terhadap nilai-nilai pancasila seringkali terdapat perbedaan kerap menimbulkan adanya kesalahan dalam penafsiran penjabaran dari suatu sila, sehingga timbul benturan antarmasyarakat yang dapat merusak persatuan dan kesatuan bangsa. Oleh karena itu, guna menghindari hal tersebut, maka diperlukan adanya penyamaan interpretasi pemahaman nilai-nilai Pancasila yang dilaksanakan melalui berbagai kegiatan sebagai berikut: a). Sosialisasi nilai-nilai pancasila dengan memanfaatkan tokoh masyarakat. Upaya sosialisasi ini dapat dilakukan oleh jajaran pemerintah setempat, anggota DPRD, serta aparat TNI atau Polri. b). Pengkajian terhadap kondisi penghayatan nilai-nilai pancasila. Upaya ini dapat dilakukan oleh jajaran pemerintahan setempat dengan melibatkan kalangan akademisi dan tokoh-tokoh masyarakat. Pengkajian dilakukan terhadap nilainilai pancasila beserta relevansinya terhadap berbagai perkembangan yang terjadi. c). Pemerintah melalui Kemendagri dan Kemendiknas merumuskan kebijaksanaan dan program penyusunan buku pedoman/ arahan umum implementasi nilai-nilai pancasila dan menjadikan buku tersebut sebagai bahan bacaan wajib bagi seluruh aparatur penyelenggara negara di berbagai instansi pemerintah, kalangan swasta maupun dunia pendidikan. d). Pemerintah melalui Kemendiknas menyusun seperangkat kebijakan dan program penataan kurikulum pendidikan materi pancasila dengan mengacu pada buku pedoman/arahan umum implementasi nilai-nilai pancasila, sehingga ada kesamaan dan kesinambungan dalam interpretasi nila-nilai pancasila dari pusat sampai ke daerah. (Chairiyah, 2014: 60).

c. Penataan Kelembagaan Formal Terstruktur Sebagai Pengawas Dan Pengembangan NilaiNilai Pancasila Secara Formal. Kelembagaan formal terstruktur yang diterapkan secara terstruktur/melembaga, maupun melalui sistem pendidikan nasional yang menyangkut program membudayakan dan memasyarakatkan pancasila di berbagai lingkungan organisasi kemasyarakatan maupun lingkungan pendidikan dapat terbentuk, sehingga dapat terwujud lembaga yang mengawasi, mengembangkan Pancasila secara formal. Untuk itu diperlukan adanya berbagai upaya sebagai berikut: a). Pemerintah/Pemda bekerjasama dengan kalangan akademisi merumuskan kebijakan pembentukan Lembaga Pengkajian dan Pelestarian Nilai-nilai. b). Pemerintah menetapkan peraturan perundang-undangan yang mengatur tugas, tanggung jawab dan kewenangan yang diberikan kepada Lembaga Pengkajian dan Pelestarian Nilai-Nilai Pancasila, agar lembaga ini memiliki dasar, pedoman dan payung hukum memadai dalam menjalan tugas dan fungsinya. c). Pemerintah/Pemda meningkatkan komunikasi, koordinasi, dan kerjasama 
dalam merumuskan berbagai aturan mengenai mekanisme kerja Lembaga Pengkajian dan Pelestarian Nilai-Nilai Pancasila dalam menjalankan tugas dan fungsinya. d). Pemerintah/Pemda melaksanakan sosialisasi secara menyeluruh mengenai keberadaan Lembaga Pengkajian dan Pelestarian Nilai-Nilai Pancasila. (Chairiyah, 2014: 60-61).

\section{SIMPULAN}

Dari pembahasan yang telah diuraikan diatas, kehidupan masyarakat sedang berada pada era globalisasi yang semakin berkembang sehingga sangat dibutuhkan penguatan karakter yang berbasis Pancasila. Dampak daripada perkembangan globalisasi, salah satunya adalah memudarnya nilai-nilai Pancasila. Nilai-nilai Pancasila sebagai wujud dan tujuan dari cita-cita bangsa Indonesia di era globalisasi ini semakin diabaikan bahkan ditinggalkan. Dengan demikian, melalui pendidikan karakter, nilai-nilai Pancasila diupayakan agar ditanamkan kembali.

\section{DAFTAR PUSTAKA}

Asmaroini, Ambiro Puji. 2017. "Menjaga Eksistensi Pancasila Dan Penerapannya Bagi Masyarakat Di Era Globalisasi". JPK: Jurnal Pancasila dan Kewarganegaraan, Vol.1, No. 2

Angaraini, Deni. 2020. "Pengamalan Nilai-Nilai Pancasila Bagi Generasi Milenial". JISOP: Jurnal Inovasi IImu Sosial dan Politik, Vol. 2, No. 1, halaman 11-18

Chairiyah. 2014. "Revitalisasi Nilai-Nalai Pancasila Sebagai Pendidikan Karakter". Trihayu: Jurnal Pendidikan ke-SD-an, Vol. 1, No. 1, halamn 54-62

Gunawan, Heri. 2012. "Pendidikan Karakter (Konsep dan Implementasi)". Bandung: Alfabeta.

Hendriana, Evinna Cindra. dan Jacobus, Arnold. 2016. "Implementasi Pendidikan Karakter di Sekolah Melalui Keteladanan Dan Pembiasaan" Jurnal Pendidikan Dasar Indonesia, Volume 1 Nomor 2. Page 25 - 29.

Kaelan. 2010. "Pendidikan Pancasila, Paradigma Offset". Yogyakarta: Tt.

Khan, Yahya. 2010. "Pendidikan Karakter Berbasis Potensi Diri: Mendongkrak Kualitas Pendidikan". Yogyakarta: Pelangi Publishing.

Kemendiknas. 2011. "Panduan Pelaksanaan Pendidikan Karakter". Jakarta

Kompri. 2015. "Manajemen Pendidikan: Komponen-komponen Elementer Kemajuan Sekolah". Yogyakarta: Ar -Ruzz Media.

Kosim, M., "Urgensi Pendidikan Karakter", Jurnal KARSA, Vol. 19, No. 1, April 2011, hlm. 88-89

Kuswantoro, Agung. (2015). "Pendidikan Karakter Melalui Public Speaking". Yogyakarta: Graha IImu.

Mahmud. 2012. "Pendidikan Karakter". Bandung: Alfabeta.

Muhtadi, Ali. (2010). "Strategi Implementasi Budi Pekerti yang Efektif di Sekolah". Jurnal Dinamika Pendidikan No. 1.

Nashir, Header. (2013). "Pendidikan Karakter Berbasis Agama dan Kebudayaan".Yogyakarta: Multipresiondo.

Saiin, Asrizal. (2017). "Reaktualisasi Nilai-Nilai Pancasila Dalam Sistem Pendidikan Nasional". Justitia Et Pax: Jurnal Hukum, Vol. 33, No. 2

Suseno, Frans Magnis. (2012). "Etika Bangsa Berbudaya Abad ke 2: Keharusan Kalaulndonesia Mau Maju". makalah Seminar Nasional Mambangun Karakter

Bangsa melalui Pemantapan Kebudayaan Nasional dan Kesadaran Historis, Diselenggarakan oleh FIB Universitas Diponegoro Semarang 30 Mei 2012.

Syarbaini, Syahrial. (2012). "Pendidikan Pancasila (Implementasi nilai-nilai karakter bangsa Di Perguruan Tinggi)". Bogor: Khalian Indonesia, Cet. Ke-5.

Yaumi, Muhammad. (2014). "Pendidikan Karakter (Landasan, pilar dan Implementasi)". Jakarta: Prenamedia Group. 